\title{
WATER, FORESTS AND GOVERNMENT ORGANIZATION ${ }^{1}$
}

\author{
By A. T. PRINCE
}

I am pleased and greatly honoured to have the opportunity of addressing this distinguished gathering and particularly to have been asked to give the keynote address for the annual meeting of the Canadian Institute of Forestry. I bring you greetings from our Minister, the Honourable Jean-Luc Pepin, our Deputy Minister, Dr. C. M. Isbister, and from my colleagues in the Department of Energy, Mines and Resources. They join me in wishing you the best success in the deliberations of this conference.

The department that I represent has a common bond with this group in that its responsibilities extend into the field of renewable resources, through its interest in water. While much of the responsibility of the Department of Energy, Mines and Resources is in the field of non-renewable resources, the field of renewable resources, relating mainly to water, is now receiving top priority attention by our department. In discharging our responsibilities in water research and investigations, we need your help and, I hope can, in turn, assist you through our specialized water programs. Your forests are the greatest single consumers of water and can be wasteful in terms of water yield to the drainage system. Good management contributes to water conservation by minimizing evaporation losses and aids greatly in flood control; poor management results in low yields of water, on the one hand, and floods and erosion on the other. Your knowledge of the terrain in the headwaters and drainage basins, and of forest management, are of tremendous importance to us; close communication is a must.

Looking briefly at the economic side, everyone is aware of the tremendous contribution that forestry, forest products, and pulp and paper make to Canada. The record is one of which this Institute can well be proud, and we in turn are pleased that we can make some contribution to you through our growing participation in the vitally important field of water. There has always been substantial rivalry between the "Big Three" resource industries of the Canadian economy, your own forestry and forest products industries, agriculture, and the mineral and metal industries of the country. In fact, at the moment, I am not entirely sure who is winning, and it may depend on how the statistics are compiled and by whom. We are all growing at a tremendous rate and can take great satisfaction in our contributions to the economy of Canada.

In selecting subject matter for this morning's address, I was first inclined to confine my remarks to a technical and scientific discussion of forests and water. However, in looking over your excellent program, I felt that a great deal of this subject would be covered much more adequately in the course of

\footnotetext{
${ }^{1}$ Keynote address given to the Annual Meeting of the Canadian Institute of Forestry, Banfr, Alberta. October, 1966.

${ }^{2}$ Director, Water Research Branch; Canada Department of Energy, Mincs and Resources, Otcawa, Ontario.
} 
your technical programs. I have, therefore, confined my remarks to a limited amount of discussion of research and have included subjects concerning departmental organization and policy in the federal government. Many things are happening in Ottawa at the present time in connection with re-organization of government departments and the significance of these changes should be of considerable interest to foresters. The evolution of policy, in relation to water, is of concern to all Canadians.

\section{Reorganization of Federal Departments}

I would like now to comment briefly on the reorganizational changes that have been made recently in some of the federal government departments. The changes have been described as "the most extensive reorganization in the responsibilities of federal government departments ever undertaken in peacetime." They affect several technical as well as administrative departments. Legislation authorizing this reorganization was passed a few months ago and new names and functions became effective on October 1, 1966. Transfers and regrouping of units have been in progress since January 1, 1966, when the government announced its intention of reorganizing several departments.

Among the technical and resource departments the following changes have occurred: The Department of Mines and Technical Surveys now becomes Energy, Mines and Resources, with the main federal energy and resource crown companies and boards reporting to the Minister. The Department of Forestry becomes the Department of Forestry and Rural Development, in recognition of its important ARDA responsibilities. The Department of Northern Affairs and National Resources becomes the Department of Indian Affairs and Northern Development.

There are several other changes, affecting administrative departments, concerning manpower, immigration, citizenship, etc., but time does not permit discussion of them. In all cases, efforts have been made to bring together, in the most logical manner, those groups that have common objectives and functions.

Taking the Department of Energy, Mines and Resources, for example, rather major changes have been made in bringing together the crown companies and related boards having to do with energy, which now report to my Minister. In addition, a very heavy input of economic planning and orientation of the resource interests of our department is planned to give guidance and leadership toward the betterment of the national economy in our particular fields of enterprise. Over the years, the Department of Mines and Technical Surveys has been recognized as an outstanding scientific organization, perhaps $I$ can say with due modesty, and it is with regret that we see its name passing from the scene. However, to meet present day needs, it was decided that more effective orientation of effort is required. As we look at it, a new dimension has been added that will not detract from the high calibre of scientific and engineering investigations but that will give them more meaning and expression to the benefit of the country as a whole.

In terms of scientific and technical reorganization within the department, some rather significant changes have been made. These relate particularly to the field of water, which, because of its importance to the country, has received special attention. 
About a year ago some five separate units in the department, affiliated with various branches, were brought together to form the Water Research Branch. These various units had been doing effective work in the fields of groundwater, water quality, glaciology, water levels and Great Lakes studies, but with a limited coordination. In bringing these units together, a new focus was given to the importance of their activities and every encouragement extended for expansion and increase in the scope of their programs.

At the end of the year, under the government reorganization plan, other water units of the government were transferred to Mines and Technical Surveys. This involved the bringing over of two branches from the Department of Northern Affairs and National Resources, namely the Water Resources Branch and part of the Resource Development Branch. The activities of the former were confined entirely to water and the latter has a substantial interest in the subject also. Various processes of coordination and assimilation have been in progress since that time.

One hesitates to use the word "integration" with respect to federal government activities at the present time, but the process is occurring nevertheless.

In support of the moves made at the beginning of the new year, our Minister was given further directives early in March, 1966, and was charged with the responsibility of coordination of federal government activities in the field of water and water pollution. He was given the responsibility of assuming "a primary and coordinating role" in this respect.

These changes, in organization and responsibility, have not been made for the sake of change but to bring about better and more effective coordination and performance in the field of water, which is so important to the future of this country.

I have outlined this matter in some detail because I feel that it is important to all agencies throughout the country, whether government or private, to know what is going on, and to assure them that such changes are being made in their own interests as well as in the interests of better management in the government service. No group is more intimately concerned with this than the foresters, who as the managers of the headwater areas of our land, can contribute so greatly to better land and water management. The facilities and talents of government service are the property of the people of Canada, and as such should be made readily available to them in the most effective manner. By having the major facilities accessible in one department, much time and effort can be saved on the part of all who may wish to avail themselves of assistance.

\section{Water Policy}

The question of what should constitute national water policy is one that affects many people in the country, emotionally, as well as having far-reaching economic and sociological implications. Water policy can only be developed through effective discussion between the politician and his advisors, technical and economic, and through the integrated views of provincial governments that have the prime responsibility for resource management and resource development. Policy is therefore very complex and evolves gradually through the meeting of minds and the interplay of circumstances. The current 
thinking, based on recent views expressed by my Minister and by his predecessors in the field of water, are worthwhile reviewing, and are summarized as follows:

The federal government recognizes the rights and responsibilities that have been given to the provinces relating to water resource development, and the management and control of water.

The government stands ready to assist the provinces and territories by financial, technical and consultation means, in the development and management of Canada's water resources.

It recognizes its own special responsibilities in the matter of interprovincial and international water problems.

It is deeply concerned with, and is taking positive action to deal with, the major problem of water pollution.

It recognizes the urgent need for a national inventory of water resources, water uses and a forecast of future needs and that such an inventory can only be obtained by the integration of provincial and federal efforts.

It is fully aware of the international pressures concerning the sharing of Canada's waters on a continental basis; that such "sharing pressures" can largely be alleviated by improved water management and control of water pollution on the part of its neighbours, and that Canada's present and future needs must be protected.

It recognizes the need for country-wide standards of water quality and management procedures, which are required to give equal opportunities for industrial and population development throughout Canada, and that preferential regional permission to degrade water is not in the national interest. It recognizes its responsibility to give leadership in all aspects of the water problem; that strong pressures of public opinion are demanding federal leadership and that only through meaningful cooperation with the provinces can such leadership be made effective.

I think that many of these matters pertaining to policy will receive particular attention at the Canadian Council of Resource Ministers' Conference on Pollution and Our Environment, to be held in Montreal at the end of this month. There are great hopes for the outcome of this meeting in defining policy and action regarding the management of our resources-water, air and soil. Much planning and organization have gone into the preparation for this meeting and I am sure that the interests of both forest and water resources will be adequately looked after, in the course of the deliberations that will take place.

While I have spent considerable time in reviewing some of the things that are taking place in Ottawa, particularly in my own department, it is my purpose to point out that these things can render more effective assistance to the forestry industry and the professional forester, where our interests converge in the fascinating field of water.

\section{Research Activities}

In the research field, I would first like to mention the program of the International Hydrologic Decade. Many of us have heard of it and may even be involved in it. The foresters are very much in the act; of 150 projects underway in Canada, about 50 relate to forest-water problems. 
The International Hydrologic Decade is a major world-wide program of tremendous significance to humanity. The nations of the world are recognizing the growing problem of water supply, are pooling their efforts, and are organizing programs to study many aspects of hydrology. This program was initiated by the United Nations, through UNESCO, and most of the nations of the world have committed substantial resources to its prosecution. Its objectives are to stimulate research in the field of water and to find out as much as possible about its occurrence, its conservation, and its utilization throughout the world. All knowledge so gained is to be integrated and shared for the benefit of mankind. This program began in 1965 and is to continue for 10 years from that date. Canada is giving strong support to the International Hydrologic Decade and many projects are already underway, sponsored by the federal and provincial governments and by many of the universities.

In discussing the impact of the International Hydrologic Decade program and the projects now being recognized under it, I do not wish to imply that no such activities existed before the Decade began. Many excellent programs have been underway in the provinces, the universities, and the federal government. What has happened is that the research aspects of these programs have been given impetus and recognition, and many new projects have been undertaken.

In Alberta, there are twelve approved International Hydrologic Decade projects essentially all of which are related to Forestry. These projects are sponsored by several provincial agencies including the Eastern Rockies Forest Conservation Board, through its Eastern Slopes (Alberta) Watershed Program, by the Alberta Research Council and the Alberta Department of Lands and Forests. Federal government support is given through the Department of Forestry (and Rural Development), by the Meteorological Branch (DOT) and by our own department through Water Resources Branch and Water Research Branch. The studies are centered at Marmot Creek, Steeter Basin, Cache-Percotte and a basin of the "Lodgepole Pine" type which may by now have been selected. Complete instrumentation of these basins is to be used for surface water, groundwater, and meteorological measurements, together with biological and water quality data collection. These observations are to be continued for a period of years during which planned forest management activities are to take place. Much valuable information on the effect of forest operations on water regime should be derived from these experiments.

Similar International Hydrologic Decade projects are underway in B.C. where my branch is cooperating with the U.B.C., Department of Forestry and private logging companies in the Okanagan area (Trapping, Esperon and Terrace Creek basin projects.)

The Water Research Branch is conducting an investigation of the hydrology of eskers in the Iroquois Falls area of Ontario, following a Department of Forestry (and Rural Development) study of bog areas in that region. These are but a few examples of the stimulating effect of the International Hydrologic Decade program and demonstrate the realistic cooperation that is resulting between foresters and hydrologists throughout the country.

The field of water pollution is one that presents special problems, some of which are of interest to the forester and some of which are indeed caused by 
the forester. One of the major problems is the use of insecticide sprays and the carry-over of residues from these sprays into the surface water or groundwater circulation. I am sure that you are fully familiar with the problems that have arisen with the entry of spray residues into the wildlife cycle both land and aquatic. No one can argue that the forester should be denied the right of using these sprays to control insect infestations in the forests, and the question arises as to what can be done to reduce the effect of residues.

Perhaps the use of sprays could be minimized by improved forest management whereby forest areas are cut before they become overmature and are insect and disease prone. This is a very effective way in which the forester could make a major contribution to the protection of our water resources.

Another possibility is the development of short-persistence, biodegradable sprays, through the cooperation of the chemical manufacturer. Every effort should be made to urge their cooperation in preparing acceptable compounds. The biodegradability characteristics of organic chemicals can be enhanced by changes in formulation and perhaps their effectiveness in the matter of insect kill can still be retained. This is a challenge to the manufacturer, but is something about which he should be reminded continuously. The stubborn stability of organochlorine insecticides such as DDT, dieldrin, endrin and similar compounds is notorious, and warnings from health authorities and wildlife conservationists must be borne in mind.

Problems of this kind have been faced up to realistically by the detergent manufacturers and the difficulties that have been experienced in the recent past, concerning the formation and the persistence of foam, have been overcome by changing the formulation of surfactant soaps from a stubborn ring-type compound to a linear compound that can be attached and decomposed by bacteria in water. I am sure that similar ingenuity can be exercised by the organic chemists who rely to a large extent on the forest industry for the sale of their products.

One other area in which the forester and the pulp and paper operator may part company with the water conservationist is in the question of large amounts of bark or fibre entering streams and lakes. The presence of excessive amounts of organic material of this kind leads to a serious depletion of the very small amount of oxygen dissolved in water. Oxygen saturation of surface waters is about 10 parts per million. Thus, the presence of large amounts of reducing materials such as bark, fibre and water liquors can rapidly deplete oxygen from rivers and lakes into which they enter. While a certain amount of bark is abraded from logs during river-driving, the major problem arises in the pulp and paper industry, where mill effluents including bark can be a very serious source of oxygen depletion, as well as giving rise to unpleasant odours and coloration in the waters below the mill.

I believe there are certain experimental techniques in forest management in which chemical sprays (arsenic compounds) are used for debarking trees, more or less in situ in the forest. This particular technique, provided the spray residue is not deleterious, would lead to many advantages in decreasing the buildup of bark in rivers and lakes.

The bark is much more valuable as forest litter than it is as river litter.

Depletion of oxygen from saturation at 10 parts per million to about 4 
parts per million leads to an undesirable environment for many of our best game fish and at levels below 4 parts per million, only coarser and less desirable types can survive. This is the problem that is being encountered at the present time in Lake Erie where municipal, industrial and other forms of waste, together with the excessive growth of algae and their subsequent decay, have led to the depletion of oxygen in large portions of that important body of water.

As an example of profitable cooperation between foresters, agriculturists, and water pollution investigators, an experiment is currently in progress at Pennsylvania State University. During the past two years, the clarified secondary treatment effluent from the local sewage disposal plant has been sprayed on plots of many acres of forest and agricultural land. Intermittent spray, on a year round basis, amounting to one or two inches per week, has been applied giving total precipitation equivalent to about 100-150 inches/year. Due to the presence of phosphate and other nutrients and to the increased precipitation, marked increases $(100-300 \%)$ have taken place in forage and other crops, and forest growth rate has accelerated perceptibly. Spraying has been conducted under winter conditions with some engineering difficulties but serious damage to forest growth, due to ice formation, has not resulted. Furthermore, the nutrients are largely extracted from the effluent in the first few inches of soil (phosphate $98.8 \%$ in 12 inches), the water table is rising, springs are being restored and a more uniform flow of headwater is evident. The implications of this experiment are of significance to the management of water, the control of pollution, and to the increased yield from forests and farms. Economic and public health factors cannot be ignored but may not constitute an insurmountable barrier to what appears to be a "good idea". This experiment is illustrated in an excellent short film "The Living Filter" that I believe is available from Pennsylvania State University.*

As you can see there are several areas where communication between the professional forester and the water conservationist can be most effective and I am sure that such areas will be developed to a greater extent in the future.

The field of water pollution is one of special interest and concern to the government of Canada, the provincial governments and essentially every municipality throughout the country. It is a world-wide problem that is receiving much attention at the present time and for which solutions will have to be found at an early date, if the precious water resource is to be preserved for human use. The forester has an important role to play in this area through improved management of forests in headwater regions which can contribute greatly to regulation of stream flow. Improved consultation between pollution control experts and foresters must be developed and exploited.

Canada has many serious and growing problems in the field of water pollution but fortunately, up to the present time, these problems have not reached a critical stage except in limited areas of the country. These areas, however, are the heavily populated regions where the effects of water

* The person to contact in connection with the film is Mr. William Small, Department of Public Information, 312 Old Main, University Park, Pa. 16802. 
pollution are most obvious and most alarming. I think it is fortunate for Canada that the "balloon has gone up" at an early stage of progress of the disease.

In the United States the problem has progressed to a much more advanced stage than in Canada, and has become one essentially of national emergency. Rigorous and effective measures are being taken by the United States federal government in the stimulation of state and municipal action to cope with the problem in all parts of the country. Similar action is being taken in Canada in the hope of intercepting the difficulty before it reaches too serious a stage. It, therefore, behooves every municipality and industry to be aware of the dangers of water pollution and to take those measures which are most effective in minimizing it. For the most part, people are not willing polluters but are involuntary or perhaps uninformed polluters. A great deal of what is needed is educational indoctrination.

Vast sums of money are being diverted towards the problem of water pollution in the United States and proportionate sums in Canada. It is recognized that no longer can industry and the municipalities take the easy and cheap way of dealing with their effluents. As you all know, there have been very strong pressures placed on Canada to divert water to the United States, to overcome its water pollution problems. This, however, in our view is not the solution to the problem, because more water merely means more polluted water. At the present time the United States authorities, as represented by Mr. Stewart Udall, Secretary of the Interior, and based on recent conversations that we held with him in Ottawa, are of the opinion that the management and abatement of pollution can go a long way toward the restoration of United States water resources, without the need for additional supplies.

The subject of water pollution, with all its implications, is one that can only be touched upon in the brief time available today, and I must leave it at this point.

\section{Concluding Comments}

This morning, I have endeavoured to cover a fairly broad range of subjects, some of which are of an administrative or a semipolitical nature and some of which deal with the questions of scientific problems that are of mutual interest to the forester and the water scientist. The subjects of administration and scientific research are closely connected because the one sets the environment and makes possible the other; the organizational side creates the framework whereby effective scientific programs can be mounted. At the present time, both fields are moving forward at an astonishing pace and are giving rise to truly fascinating prospects of progress.

In closing may I again express my wishes for success in the deliberations of the Canadian Institute of Forestry, which will take place during the next few days. May they lead to productive communication and most fruitful discussion. 